\title{
Potassium forms in calcareous soils as affected by clay minerals and soil development in Kohgiluyeh and Boyer-Ahmad Province, Southwest Iran
}

\author{
Sirous SHAKERI ${ }^{1 *}$, Seyed A ABTAHI ${ }^{2}$ \\ ${ }^{1}$ Department of Agriculture, Payame Noor University, Tehran 19395-3697, Iran; \\ ${ }^{2}$ Department of Soil Science, College of Agriculture, Shiraz University, Shiraz 71964-84334, Iran
}

\begin{abstract}
Potassium $(\mathrm{K})$ is known as one of the essential nutrients for the growth of plant species. The relationship between $\mathrm{K}$ and clay minerals can be used to understand the $\mathrm{K}$ cycling, and assess the plant uptake and potential of soil $\mathrm{K}$ fertility. This study was conducted to analyze the $\mathrm{K}$ forms (soluble, exchangeable, non-exchangeable and structural) and the relationship of $\mathrm{K}$ forms with clay minerals of calcareous soils in Kohgiluyeh and Boyer-Ahmad Province, Southwest Iran. The climate is hotter and drier in the west and south of the province than in the east and north of the province. A total of 54 pedons were dug in the study area and 32 representative pedons were selected. The studied pedons were mostly located on calcareous deposits. The soils in the study area can be classified into 5 orders including Entisols, Inceptisols, Mollisols, Alfisols and Vertisols. The main soil clay minerals in the west and south of the study area were illite, chlorite and palygorskite, whereas they were smectite, vermiculite and illite in the north and east of the province. Due to large amount of smectite and high content of organic carbon in soil surface, the exchangeable $\mathrm{K}$ in surface soils was higher than that in subsurface soils. It seems that organic matter plays a more important role than smectite mineral in retaining exchangeable $\mathrm{K}$ in the studied soils. Non-exchangeable K exhibited close relationships with clay content, illite, vermiculite and smectite. Although the amount of illite was the same in almost all pedons, amounts of structural and non-exchangeable $\mathrm{K}$ were higher in humid regions than in arid and semi-arid regions. This difference may be related to the poor reservoir of $\mathrm{K}^{+}$minerals like palygorskite and chlorite together with illite in arid and semi-arid regions. In humid areas, illite was accompanied by vermiculite and smectite as the $\mathrm{K}^{+}$reservoir. Moreover, the mean cumulative non-exchangeable $\mathrm{K}$ released by $\mathrm{CaCl}_{2}$ was higher than that released by oxalic acid, which may be due to the high buffering capacity resulting from high carbonates in soils.
\end{abstract}

Keywords: clay minerals; potassium forms; calcareous soils; oxalic acid; $\mathrm{K}^{+}$reservoir; Iran

Citation: Sirous SHAKERI, Seyed A ABTAHI. 2018. Potassium forms in calcareous soils as affected by clay minerals and soil development in Kohgiluyeh and Boyer-Ahmad Province, Southwest Iran. Journal of Arid Land, 10(2): $217-232$. https://doi.org/10.1007/s40333-018-0052-8

\section{Introduction}

Potassium (K) is known as one of the essential nutrients for the natural growth of plant species (Sparks and Huang, 1985; Islam et al., 2016). The average percentage of $\mathrm{K}$ in the Earth's crust is about $2.3 \%$, of which a large quantity is present in the secondary clay minerals. Soil K content could vary based on the type of clay minerals (Mengel and Kirkby, 2001). A large amount of total

\footnotetext{
${ }^{*}$ Corresponding author: Sirous SHAKERI (E-mail: shakeri@pnu.ac.ir)

Received 2017-04-07; revised 2017-11-08; accepted 2017-12-13

(C) Xinjiang Institute of Ecology and Geography, Chinese Academy of Sciences, Science Press and Springer-Verlag GmbH Germany, part of Springer Nature 2018
} 
$\mathrm{K}$ pools in soils can be caused by the presence of high quantity of $\mathrm{K}$ bearing minerals in soils. Muscuvite (60-90 g/ $/ \mathrm{kg} \mathrm{K})$, biotite (36-80 g/ $/ \mathrm{kg} \mathrm{K})$, illite (32-56 g/ $\mathrm{kg} \mathrm{K}$ ) and K-feldespars (20-30 $\mathrm{g} / \mathrm{kg} \mathrm{K}$ ) are the most important $\mathrm{K}$ pools in soils (Mengel, 2006). A long-term non-application of $\mathrm{K}$ would cause a large amount of soil $\mathrm{K}$ to be depleted (Tan et al., 2017). In arid and semi-arid regions, intensive agriculture without application of $\mathrm{K}$ fertilizer could cause a decrease of $\mathrm{K}$ in soils, despite a large amounts of $\mathrm{K}$ exist in soils (Jalali, 2006). Soil K exists in four forms, including soluble, exchangeable, non-exchangeable and structural forms. Soluble and exchangeable $\mathrm{K}$ forms are released rapidly into the soil and are readily available for plants. In addition, a recent study showed that these forms of $\mathrm{K}$ are considerably higher in surface soil layer than in subsurface soil layer ( $\mathrm{Li}$ et al., 2017). There are dynamic equilibrium reactions between different forms of $\mathrm{K}$ in soils. The level of soluble $\mathrm{K}$ in soils depends on the $\mathrm{K}$ depletion by plant uptake, leaching, released $\mathrm{K}$ by clay minerals and replacement by other $\mathrm{K}$ forms such as exchangeable and non-exchangeable K (Kirkman et al., 1994). The distribution of soil $\mathrm{K}$ forms in surface soil layer is distinctly influenced by soil forming processes (i.e., parent materials and soil types) for total K, and mostly influenced by land use changes (i.e., agricultural practices) for exchangeable and available $\mathrm{K}$ forms (Blanchet et al., 2017). Exchangeable $\mathrm{K}$ is electrostatically retained on the outer surface of clay and humic substances, and is available for plants (Barré et al., 2008). Non-exchangeable K plays an important role in supplying available K, particularly in soils containing K-bearing minerals (Raheb and Heidari, 2012). This form of $\mathrm{K}$ is fixed in interlayer of 2:1 clay minerals and could be released gradually (Rees et al., 2013). The composition of parent rocks and soil development stages can determine the amount of structural or mineral $\mathrm{K}$ in soils (Sparks and Huang, 1985). The roles of 2:1 clay minerals are very important in soil K cycle. Adsorption and desorption of $\mathrm{K}$ have negative correlations with soil buffering capacity and soils with 2:1 clay minerals like illite, vermiculite and smectite (Sparks and Huang, 1985). Soils differ in tendencies to fix the applied $\mathrm{K}$ in forms unavailable to plants and each soil has its fixing capacity for K, which must be satisfied before a change in soil solution occurs (Anil et al., 2016). Wood and Schroeder (1991) reported that releasing of non-exchangeable K can be affected by the type of clay minerals. Their results showed that soils containing 2:1 clay minerals release more $\mathrm{K}$ than soils with 1:1 clay minerals as dominant clays.

There are lots of researches about the distribution and genesis of clay minerals in soils of Iran as well as in other arid and semi-arid regions in the world (Abtahi, 1980; Ghosh and Singh, 2001; Owliaie et al., 2006; Barré et al., 2008; Anil et al., 2016). The predominant minerals in calcareous soils of Iran are illite, chlorite, kaolinite, palygorskite, smectite and vermiculite, with origins of inheritance, transformation, and neoformation. Due to the high $\mathrm{pH}$ values and large amounts of $\mathrm{Si}^{4+}$ and $\mathrm{Mg}^{2+}$, vermiculite is a rare clay mineral, especially in arid and semi-arid regions of Iran (Abtahi, 1980; Khormali and Abtahi, 2003; Owliaie et al., 2006).

Understanding the soil mineralogy and fertilization background is essential to reduce $\mathrm{K}$ loss and obtain high crop production in agricultural lands (Moterle et al., 2016). Though several researches have been done concerning $\mathrm{K}$ release and $\mathrm{K}$ fixation, there is no sufficient information about $\mathrm{K}$ forms and the relationship between $\mathrm{K}$ forms and clay minerals, especially in calcareous soils. The relationship between $\mathrm{K}$ forms and clay minerals can be used to analyze the $\mathrm{K}$ cycling, and assess the plant uptake and potential of soil $\mathrm{K}$ fertility. Kohgiluyeh and Boyer-Ahmad Province in Southwest Iran is a region with a large variety of climate and landforms. However, comprehensive investigations about $\mathrm{K}$ forms and clay minerals have not been systematically carried out in this region. Thus, this study was conducted to analyze the $\mathrm{K}$ forms (soluble, exchangeable, non-exchangeable and structural) and the relationship of $\mathrm{K}$ forms with clay minerals of calcareous soils in Kohgiluyeh and Boyer-Ahmad Province, Southwest Iran.

\section{Materials and methods}

\subsection{Study area}

This study was conducted in Kohgiluyeh and Boyer-Ahmad Province $\left(30^{\circ} 09^{\prime}-31^{\circ} 32^{\prime} \mathrm{N}\right.$, 
$49^{\circ} 57^{\prime}-51^{\circ} 42^{\prime} \mathrm{E}$; $500-4409 \mathrm{~m}$ a.s.1.), Southwest Iran. It has a land area of $16.264 \times 10^{3} \mathrm{~km}^{2}$ and contains some intermountain plains within the middle Zagros Mountains. The climate is hotter and drier in the west and south of the province than in the east and north of the province and, therefore, the province is divided into two climatic zones: (1) east region with xeric soil moisture regime and mesic soil temperature regime; and (2) west region with ustic soil moisture regime, and thermic and hyperthermic soil temperature regime. Annual mean temperature ranges from $14^{\circ} \mathrm{C}$ to $25^{\circ} \mathrm{C}$ and mean annual precipitation ranges from 372 to $830 \mathrm{~mm}$ (Fig. 1).

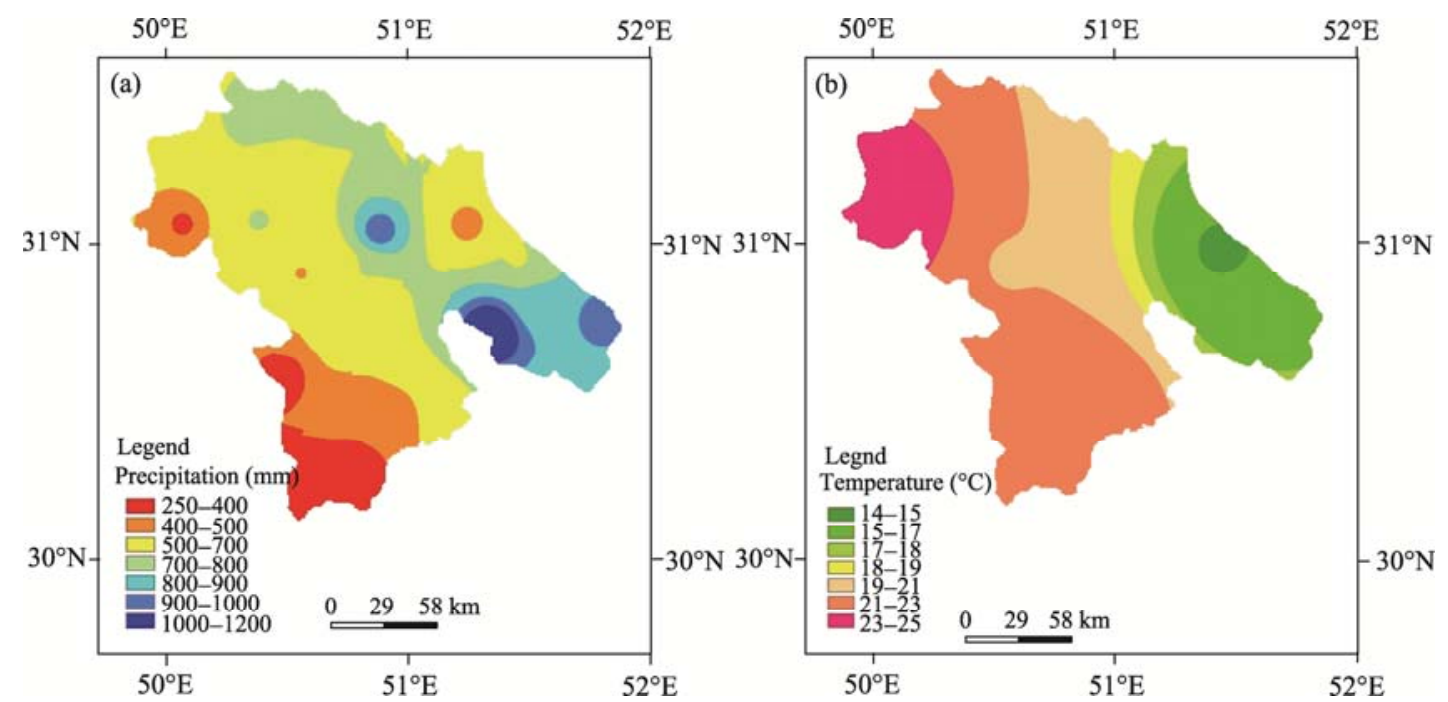

Fig. 1 Mean annual precipitation (a) and annual mean temperature (b) in Kohgiluyeh and Boyer-Ahmad Province

\subsection{Soil sampling and analysis}

We dug a total of 54 pedons in the study area based on aerial photos, topographic maps and physiographic units, and the distribution of these 54 pedons is shown in Figure 2. We finally selected 32 representative pedons located on calcareous deposits to determine the physical-chemical properties, mineralogical characteristics and different $\mathrm{K}^{+}$forms. We collected 64 soil samples from the 32 representative pedons (in duplicate) according to genetic horizons. The samples were air-dried and then sieved through a mesh size of $2 \mathrm{~mm}$. Soil particle-size distribution was determined using the hydrometer method (Bouyoucos, 1962). Calcium carbonate equivalent (CCE) was measured by neutralization with $\mathrm{HCl}$ (Loeppert and Suarez, 1996), and organic carbon (OC) was determined by wet oxidation method (Nelson and Sommers, 1996). Soil $\mathrm{pH}$ was measured using the saturated paste extract, electrical conductivity (EC) was measured in soil saturation extract using conductometer, saturation percentage (SP) was determined using the saturated paste extract, cation exchangeable capacity (CEC) was analyzed by replacing exchangeable cations by $\mathrm{NaOAc}$ and exchanging $\mathrm{Na}^{+}$with $\mathrm{NH}_{4} \mathrm{OAc}$ (Chapman, 1965), and gypsum was measured by precipitation with acetone (Richards, 1954).

Soluble $\mathrm{K}$ was measured in the saturated extract, and exchangeable $\mathrm{K}$ was extracted by $1.0 \mathrm{M}$ $\mathrm{NH}_{4} \mathrm{OAc}$ at $\mathrm{pH} 7.0$ (McLean and Watson, 1985). Non-exchangeable $\mathrm{K}$ was extracted by boiling 1.0 $\mathrm{M} \mathrm{HNO}_{3}$ (Pratt, 1965). Digestion by aqua regia HF method was carried out to determine the total $\mathrm{K}^{+}$(Buckley and Cranston, 1971). For assessing the cumulative non-exchangeable $\mathrm{K}$ release with time, we firstly removed the native $\mathrm{K}$ with saturation by equilibrating $10 \mathrm{~g}$ of soil with $1 \mathrm{M}$ $\mathrm{CaCl}_{2}$ three times for $48 \mathrm{~h}$. We then washed out the extra $\mathrm{Cl}^{-}$by alcohol and deionized water. Samples were dried at $65^{\circ} \mathrm{C}$. For each soil sample (64 in total), $2 \mathrm{~g}$ of Ca-saturated soil was placed in two centrifuge tubes (in duplicate) with different media including $0.01 \mathrm{M} \mathrm{CaCl}_{2}$ and $0.01 \mathrm{M}$ oxalic acid solutions (20 mL in each tube) for $1948 \mathrm{~h}(2,4,8,14,24,36,48,72,96,144$, $192,268,436,604,940,1444$ and $1948 \mathrm{~h}$ ) at $25^{\circ} \mathrm{C}$. Subsequently, they were shaken for $1 \mathrm{~h}$ before 
the suspensions were centrifuged for $10 \mathrm{~min}$. At each stage, the supernatant liquid was determined for K using the flame photometer (Elico Model CL-360, India) (Martin and Sparks, 1983).

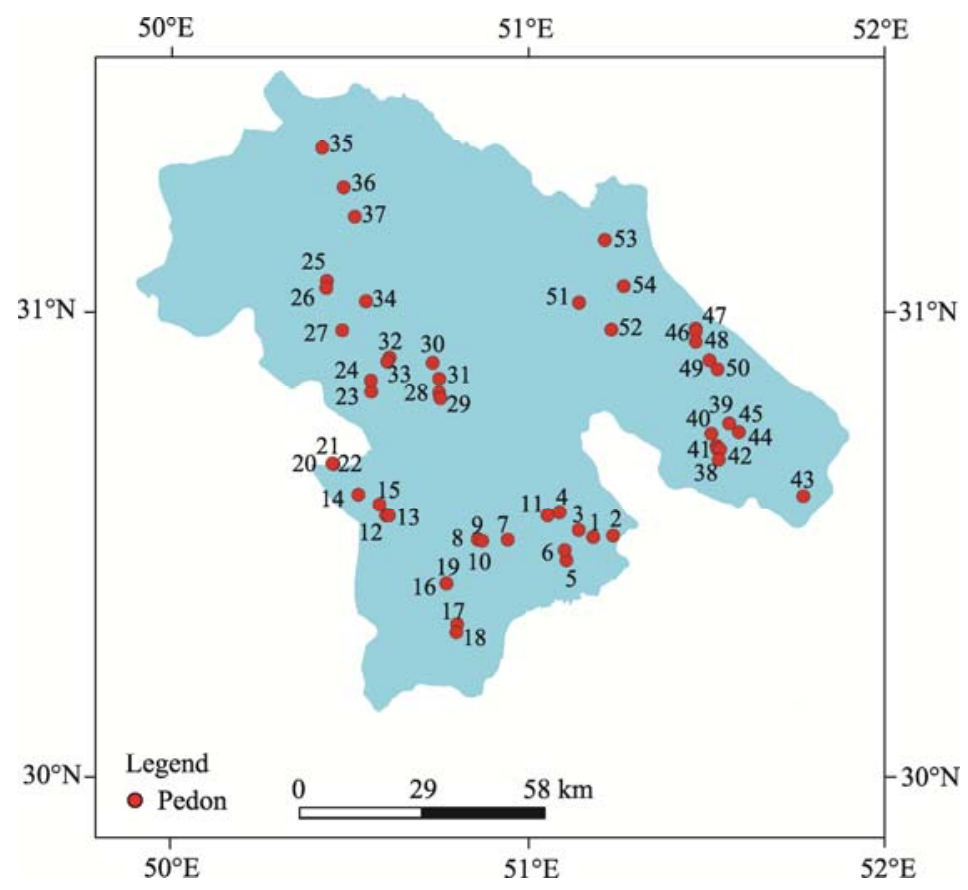

Fig. 2 Locations of the 54 pedons in Kohgiluyeh and Boyer-Ahmad Province

\subsection{Clay mineralogy analysis}

To prepare soil samples for clay mineral analyses, we removed the cementation agents including carbonates, organic matter and iron oxides by $1 \mathrm{~N} \mathrm{HCl}, 30 \% \mathrm{H}_{2} \mathrm{O}_{2}$, and dithionite citrate bicarbonate mixed solution, respectively (Mehra and Jackson, 1960; Kittrick and Hope, 1963; Jackson, 1975). Samples containing gypsum were washed with distilled water. After separation of clay fraction, samples were saturated with $\mathrm{Mg}^{2+}$ and $\mathrm{K}^{+}$, using $1 \mathrm{~N} \mathrm{MgCl}_{2}$ and $1 \mathrm{~N} \mathrm{KCl}$, respectively. The $\mathrm{Mg}^{2+}$ - and $\mathrm{K}^{+}$-saturated samples were saturated by ethylene glycol and heated at $550^{\circ} \mathrm{C}$, respectively. In addition, samples were treated with $1 \mathrm{~N} \mathrm{HCl}$ to discriminate kaolinite and Fe chlorite. These five treatments $\left(\mathrm{Mg}^{2+}\right.$-saturated, $\mathrm{K}^{+}$-saturated, Mg-ethylene glycol (Mg-EG), $\mathrm{K}-550^{\circ} \mathrm{C}$ and $\mathrm{HCL}$ treatments) were analyzed by XRD (X-ray diffraction) diffraction. Relative abundance of clay minerals based on peak intensities was semi-quantitatively measured following the method of Johns et al. (1954).

\subsection{Data analysis}

Soils in the study area were classified according to the U.S. Soil Taxonomy (Soil Survey Staff, 2014). Statistical analyses were performed by Microsoft Excel 2010 and SPSS 19.0.

\section{Results and discussion}

\subsection{Soil characteristics}

Soil classification of the studied pedons according to the U.S. Soil Taxonomy (Soil Survey Staff, 2014) is shown in Table 1. Soils were classified into 5 orders, including Entisols, Inceptisols, Mollisols, Alfisols and Vertisols. Soils with argillic horizon (pedons 38, 42, 44, 45, 49, 51 and 52) were developed mostly in the east and northeast of Kohgiluyeh and Boyer-Ahmad Province with high precipitation, although few developed soils (pedons 2, 7, 23 and 33) were also observed in other regions with low precipitation. The formation of argillic horizon in this region may be due to the process of dealkalization and steppification in the past (Abtahi, 1977). Soils with argillic 
Table 1 Soil characteristics of the studied pedons

\begin{tabular}{|c|c|c|c|c|c|c|c|c|c|c|c|c|}
\hline Pedon & Horizon & $\begin{array}{c}\text { Sand } \\
(\%)\end{array}$ & $\begin{array}{l}\text { Silt } \\
(\%)\end{array}$ & $\begin{array}{l}\text { Clay } \\
(\%)\end{array}$ & $\begin{array}{l}\text { SP } \\
(\%)\end{array}$ & $\mathrm{pH}$ & $\begin{array}{c}\mathrm{EC} \\
(\mathrm{dS} / \mathrm{m})\end{array}$ & $\begin{array}{l}\text { CCE } \\
(\%) \\
\end{array}$ & $\begin{array}{c}\text { Gypsum } \\
(\%)\end{array}$ & $\begin{array}{l}\mathrm{OC} \\
(\%)\end{array}$ & $\begin{array}{c}\mathrm{CEC} \\
(\mathrm{cmol} / \mathrm{kg})\end{array}$ & Taxonomy \\
\hline \multirow[t]{4}{*}{1} & Ap & 27.3 & 36.0 & 36.7 & 48.3 & 7.9 & 0.7 & 44.1 & $\operatorname{Tr}$ & 1.16 & 15.6 & Typic Haplustolls \\
\hline & Bw1 & 34.0 & 30.6 & 35.4 & 43.3 & 7.9 & 0.8 & 65.9 & $\operatorname{Tr}$ & 0.67 & 13.0 & \\
\hline & Bw2 & 58.0 & 13.3 & 28.7 & 38.7 & 7.9 & 0.6 & 82.2 & $\operatorname{Tr}$ & 0.45 & 11.1 & \\
\hline & IIC & 29.4 & 17.3 & 53.3 & 51.3 & 8.2 & 0.4 & 56.7 & $\operatorname{Tr}$ & 0.47 & 11.1 & \\
\hline \multirow[t]{5}{*}{2} & Ap & 19.3 & 43.3 & 37.4 & 54.2 & 7.8 & 0.7 & 45.4 & $\operatorname{Tr}$ & 1.08 & 21.7 & Calcidic Argiustolls \\
\hline & $\mathrm{A} / \mathrm{B}$ & 17.3 & 37.3 & 45.4 & 50.4 & 8.0 & 0.5 & 40.2 & $\operatorname{Tr}$ & 1.03 & 18.4 & \\
\hline & $\mathrm{Bk} 1$ & 32.0 & 33.3 & 34.7 & 41.3 & 8.1 & 0.4 & 59.6 & $\operatorname{Tr}$ & 0.74 & 14.3 & \\
\hline & $\mathrm{Bk} 2$ & 26.9 & 37.6 & 35.4 & 65.2 & 8.2 & 0.3 & 53.9 & $\operatorname{Tr}$ & 0.79 & 13.3 & \\
\hline & $\mathrm{Bk} 3$ & 27.3 & 38.0 & 34.7 & 45.9 & 8.2 & 0.4 & 55.4 & $\operatorname{Tr}$ & 0.74 & 12.4 & \\
\hline \multirow[t]{3}{*}{3} & Ap & 36.0 & 36.6 & 27.4 & 48.5 & 7.9 & 0.6 & 40.2 & $\operatorname{Tr}$ & 1.59 & 19.1 & Typic Calciustepts \\
\hline & Bk1 & 21.3 & 41.0 & 37.7 & 42.8 & 8.0 & 0.4 & 45.4 & $\operatorname{Tr}$ & 1.02 & 19.8 & \\
\hline & $\mathrm{Bk} 2$ & 25.3 & 37.0 & 37.7 & 44.2 & 8.1 & 0.3 & 42.3 & $\operatorname{Tr}$ & 0.47 & 14.6 & \\
\hline \multirow[t]{3}{*}{5} & Ap & 28.0 & 44.6 & 27.4 & 48.6 & 7.9 & 0.7 & 55.2 & $\operatorname{Tr}$ & 0.96 & 11.1 & Aridic Calciustepts \\
\hline & Bk1 & 23.3 & 42.0 & 34.7 & 52.6 & 8.0 & 0.3 & 53.9 & $\operatorname{Tr}$ & 0.51 & 9.4 & \\
\hline & $\mathrm{Bk} 2$ & 28.0 & 35.3 & 36.7 & 49.9 & 7.5 & 0.4 & 56.7 & $\operatorname{Tr}$ & 0.43 & 12.4 & \\
\hline \multirow[t]{3}{*}{7} & Ap & 46.0 & 26.6 & 27.4 & 34.5 & 7.9 & 0.8 & 60.7 & $\operatorname{Tr}$ & 1.23 & 13.6 & Calcidic Haplustalfs \\
\hline & Btk1 & 25.3 & 38.0 & 36.7 & 49.2 & 7.9 & 0.5 & 67.8 & $\operatorname{Tr}$ & 0.74 & 9.4 & \\
\hline & $\mathrm{Bk} 2$ & 32.9 & 37.6 & 29.4 & 43.0 & 7.8 & 1.1 & 65.2 & $\operatorname{Tr}$ & 0.45 & 9.4 & \\
\hline \multirow[t]{3}{*}{11} & Ap & 51.3 & 27.3 & 21.4 & 46.9 & 7.9 & 0.7 & 65.2 & $\operatorname{Tr}$ & 1.34 & 14.0 & Typic Ustifluvents \\
\hline & $\mathrm{C} 1$ & 46.0 & 24.6 & 29.4 & 36.9 & 7.7 & 1.2 & 62.0 & $\operatorname{Tr}$ & 0.90 & 14.3 & \\
\hline & $\mathrm{C} 2$ & 59.3 & 21.3 & 19.4 & 32.5 & 7.9 & 0.5 & 74.6 & $\operatorname{Tr}$ & 0.72 & 12.4 & \\
\hline \multirow[t]{4}{*}{12} & Ap & 36.9 & 39.6 & 23.4 & 49.6 & 7.5 & 1.6 & 58.1 & 1.7 & 0.52 & 11.1 & Gypsic Haplustepts \\
\hline & By1 & 22.0 & 31.3 & 46.7 & 38.8 & 7.7 & 1.9 & 58.3 & 8.2 & 0.45 & 9.4 & \\
\hline & By2 & 53.3 & 15.3 & 31.4 & 45.3 & 7.7 & 1.8 & 27.0 & 50.3 & 0.49 & 13.3 & \\
\hline & By3 & 32.0 & 43.3 & 24.7 & 61.6 & 7.6 & 1.9 & 32.0 & 34.4 & 0.25 & 12.2 & \\
\hline \multirow[t]{3}{*}{13} & Ap & 37.3 & 43.3 & 19.4 & 35.1 & 7.6 & 2.1 & 64.1 & 0.4 & 0.88 & 7.4 & Gypsic Haplustepts \\
\hline & By & 29.3 & 33.3 & 37.4 & 49.3 & 7.7 & 0.5 & 59.4 & 4.5 & 0.90 & 8.8 & \\
\hline & IIC & 72.0 & 17.3 & 10.7 & 41.0 & 7.7 & 3.7 & 68.8 & 15.0 & 0.54 & 12.4 & \\
\hline \multirow[t]{3}{*}{15} & Ap & 51.3 & 32.0 & 16.7 & 29.7 & 8.0 & 0.6 & 53.3 & 0.4 & 0.52 & 9.1 & Gypsic Haplustepts \\
\hline & $\mathrm{C} 1$ & 53.3 & 27.3 & 19.4 & 36.4 & 7.6 & 2.0 & 80.9 & 3.2 & 0.41 & 7.1 & \\
\hline & $\mathrm{C} 2$ & 51.3 & 29.3 & 19.4 & 34.8 & 7.5 & 1.9 & 67.3 & 5.1 & 0.38 & 9.1 & \\
\hline \multirow[t]{3}{*}{17} & Ap & 63.3 & 25.3 & 11.4 & 69.0 & 7.7 & 0.8 & 88.0 & 0.4 & 0.87 & 6.4 & Aridic Ustifluvents \\
\hline & $\mathrm{C} 1$ & 62.0 & 23.3 & 14.7 & 33.2 & 7.9 & 0.4 & 63.8 & $\operatorname{Tr}$ & 0.58 & 6.4 & \\
\hline & $\mathrm{C} 2$ & 49.3 & 36.0 & 14.7 & 33.8 & 7.7 & 0.8 & 51.2 & $\operatorname{Tr}$ & 0.88 & 7.0 & \\
\hline \multirow[t]{2}{*}{21} & Ap & 17.3 & 47.3 & 35.4 & 55.8 & 7.3 & 2.4 & 61.0 & 0.5 & 1.41 & 11.8 & Typic Fluviaquents \\
\hline & $\mathrm{Cg}$ & 36.0 & 33.3 & 30.7 & 54.4 & 7.7 & 1.4 & 66.2 & $\operatorname{Tr}$ & 1.05 & 11.1 & \\
\hline \multirow[t]{3}{*}{23} & Ap & 45.3 & 35.3 & 19.4 & 34.2 & 8.1 & 0.6 & 65.2 & $\operatorname{Tr}$ & 0.72 & 10.5 & Calcic Haplxeralfs \\
\hline & Btk1 & 23.3 & 39.3 & 37.4 & 51.2 & 7.9 & 1.3 & 67.0 & 0.5 & 0.65 & 12.4 & \\
\hline & $\mathrm{Bk} 2$ & 56.0 & 16.6 & 27.4 & 40.7 & 8.2 & 0.3 & 69.8 & $\operatorname{Tr}$ & 0.43 & 9.4 & \\
\hline \multirow[t]{3}{*}{26} & Ap & 32.0 & 34.6 & 33.4 & 42.7 & 7.8 & 0.5 & 51.3 & $\operatorname{Tr}$ & 1.25 & 18.4 & Calcic Haploxerepts \\
\hline & Bk1 & 38.0 & 31.3 & 30.7 & 41.3 & 7.8 & 0.4 & 57.5 & $\operatorname{Tr}$ & 0.92 & 15.6 & \\
\hline & $\mathrm{Bk} 2$ & 54.0 & 20.6 & 25.4 & 34.5 & 7.9 & 0.3 & 71.7 & 0.6 & 0.81 & 11.1 & \\
\hline \multirow[t]{3}{*}{29} & Ap & 32.0 & 35.3 & 32.7 & 43.9 & 7.8 & 1.3 & 62.3 & $\operatorname{Tr}$ & 0.96 & 17.0 & Typic Xerofluvents \\
\hline & $\mathrm{C} 1$ & 77.3 & 9.3 & 13.4 & 26.2 & 8.2 & 0.3 & 90.7 & $\operatorname{Tr}$ & 0.41 & 5.5 & \\
\hline & $\mathrm{C} 2$ & 63.3 & 17.3 & 19.4 & 40.1 & 8.1 & 0.2 & 74.9 & $\operatorname{Tr}$ & 0.65 & 9.4 & \\
\hline \multirow[t]{3}{*}{30} & Ap & 36.0 & 27.3 & 36.7 & 42.8 & 7.9 & 0.5 & 70.2 & $\operatorname{Tr}$ & 1.34 & 16.3 & Fluventic Haploxerepts \\
\hline & Bw1 & 53.3 & 10.0 & 36.7 & 40.0 & 8.1 & 0.3 & 69.9 & 0.5 & 0.60 & 11.8 & \\
\hline & Bw2 & 47.3 & 23.3 & 29.4 & 37.3 & 8.4 & 0.3 & 81.7 & $\operatorname{Tr}$ & 0.70 & 7.7 & \\
\hline \multirow[t]{4}{*}{33} & Ap & 17.3 & 45.3 & 37.4 & 45.6 & 7.6 & 0.1 & 41.8 & $\operatorname{Tr}$ & 1.50 & 17.7 & Calcic Haploxeralfs \\
\hline & Btk1 & 15.3 & 32.0 & 52.7 & 49.3 & 7.7 & 0.8 & 49.4 & $\operatorname{Tr}$ & 0.70 & 15.0 & \\
\hline & $\mathrm{Bk} 2$ & 11.3 & 38.0 & 50.7 & 44.3 & 8.0 & 1.9 & 56.0 & $\operatorname{Tr}$ & 0.60 & 16.3 & \\
\hline & $\mathrm{Bk} 3$ & 22.9 & 27.6 & 49.4 & 42.2 & 7.7 & 2.1 & 59.1 & $\operatorname{Tr}$ & 0.60 & 12.4 & \\
\hline
\end{tabular}


Continued

\begin{tabular}{|c|c|c|c|c|c|c|c|c|c|c|c|c|}
\hline Pedon & Horizon & $\begin{array}{c}\text { Sand } \\
(\%)\end{array}$ & $\begin{array}{l}\text { Silt } \\
(\%)\end{array}$ & $\begin{array}{l}\text { Clay } \\
(\%)\end{array}$ & $\begin{array}{l}\text { SP } \\
(\%)\end{array}$ & $\mathrm{pH}$ & $\begin{array}{c}\mathrm{EC} \\
(\mathrm{dS} / \mathrm{m})\end{array}$ & $\begin{array}{c}\text { CCE } \\
(\%)\end{array}$ & $\begin{array}{c}\text { Gypsum } \\
(\%)\end{array}$ & $\begin{array}{l}\mathrm{OC} \\
(\%)\end{array}$ & $\begin{array}{c}\mathrm{CEC} \\
(\mathrm{cmol} / \mathrm{kg})\end{array}$ & Taxonomy \\
\hline 33 & $\mathrm{C}$ & 24.0 & 28.6 & 47.4 & 46.0 & 7.9 & 1.7 & 56.7 & 0.5 & 0.78 & 13.6 & Calcic Haploxeralfs \\
\hline \multirow[t]{3}{*}{34} & Ap & 29.3 & 39.3 & 31.4 & 47.7 & 7.9 & 0.4 & 45.2 & $\operatorname{Tr}$ & 0.90 & 15.0 & Typic Xerorthents \\
\hline & $\mathrm{C} 1$ & 38.0 & 27.3 & 34.7 & 40.2 & 7.9 & 0.3 & 87.2 & $\operatorname{Tr}$ & 0.78 & 11.1 & \\
\hline & $\mathrm{Cr}$ & 27.3 & 39.3 & 33.4 & 37.7 & 8.2 & 0.8 & 83.6 & $\operatorname{Tr}$ & 0.52 & 11.8 & \\
\hline \multirow[t]{3}{*}{35} & Ap & 23.3 & 32.0 & 44.7 & 49.8 & 7.8 & 0.4 & 44.7 & 0.5 & 0.79 & 21.3 & Typic Calcixerepts \\
\hline & Bk1 & 25.3 & 27.3 & 47.4 & 45.5 & 8.2 & 0.3 & 77.8 & 0.5 & 0.56 & 19.8 & \\
\hline & $\mathrm{Bk} 2$ & 36.0 & 19.5 & 44.5 & 54.5 & 8.1 & 0.2 & 79.9 & $\operatorname{Tr}$ & 0.25 & 19.1 & \\
\hline \multirow[t]{3}{*}{36} & $\mathrm{~A}$ & 37.3 & 35.3 & 37.3 & 71.1 & 7.4 & 1.3 & 37.3 & $\operatorname{Tr}$ & 5.25 & 39.0 & Typic Haploxerolls \\
\hline & $\mathrm{Bw}$ & 37.3 & 32.0 & 37.3 & 47.2 & 7.9 & 0.3 & 54.6 & $\operatorname{Tr}$ & 1.43 & 22.0 & \\
\hline & $\mathrm{C}$ & 28.0 & 37.3 & 28.0 & 40.5 & 8.0 & 0.3 & 67.0 & $\operatorname{Tr}$ & 0.60 & 9.9 & \\
\hline \multirow[t]{3}{*}{38} & Ap & 21.3 & 33.3 & 45.4 & 54.3 & 8.0 & 0.3 & 24.9 & $\operatorname{Tr}$ & 0.69 & 26.7 & Pachic Argixerolls \\
\hline & Bt1 & 15.3 & 31.3 & 53.4 & 54.4 & 7.9 & 0.3 & 26.8 & $\operatorname{Tr}$ & 0.87 & 29.2 & \\
\hline & Bt2 & 19.3 & 20.0 & 60.7 & 71.3 & 8.3 & 0.3 & 24.2 & $\operatorname{Tr}$ & 0.68 & 33.5 & \\
\hline \multirow[t]{3}{*}{39} & Ap & 15.3 & 39.3 & 45.4 & 47.1 & 7.8 & 0.6 & 9.7 & $\operatorname{Tr}$ & 1.14 & 30.1 & Chromic Calcixererts \\
\hline & Bkss1 & 16.9 & 33.6 & 49.4 & 27.7 & 7.8 & 0.3 & 17.6 & $\operatorname{Tr}$ & 0.40 & 30.1 & \\
\hline & Bkss2 & 17.3 & 35.3 & 47.4 & 56.7 & 8.2 & 0.4 & 18.6 & $\operatorname{Tr}$ & 0.38 & 25.9 & \\
\hline \multirow[t]{3}{*}{40} & Ap & 15.3 & 42.0 & 42.7 & 55.2 & 7.8 & 0.5 & 20.2 & $\operatorname{Tr}$ & 1.26 & 26.7 & Aquic Haploxerepts \\
\hline & $\mathrm{Bg} 1$ & 17.3 & 33.3 & 49.4 & 64.1 & 7.8 & 0.4 & 17.3 & $\operatorname{Tr}$ & 0.47 & 31.8 & \\
\hline & $\mathrm{Bg} 2$ & 17.3 & 38.0 & 44.7 & 48.6 & 8.0 & 0.4 & 16.0 & $\operatorname{Tr}$ & 1.21 & 25.9 & \\
\hline \multirow[t]{3}{*}{42} & Ap & 23.3 & 37.3 & 39.4 & 54.6 & 7.8 & 0.6 & 28.1 & $\operatorname{Tr}$ & 2.20 & 34.4 & Mollic Haploxeralfs \\
\hline & Bt1 & 23.3 & 28.0 & 48.7 & 53.9 & 7.8 & 0.3 & 31.0 & $\operatorname{Tr}$ & 0.78 & 32.6 & \\
\hline & $\mathrm{Bt} 2$ & 44.9 & 19.6 & 35.4 & 49.4 & 7.9 & 0.3 & 44.7 & $\operatorname{Tr}$ & 0.49 & 25.1 & \\
\hline \multirow[t]{4}{*}{44} & Ap & 32.0 & 22.6 & 45.4 & 57.9 & 7.9 & 0.6 & 42.8 & $\operatorname{Tr}$ & 1.91 & 26.7 & Mollic Haploxeralfs \\
\hline & Bt1 & 14.9 & 33.6 & 51.4 & 57.4 & 8.0 & 0.3 & 43.9 & $\operatorname{Tr}$ & 0.61 & 22.8 & \\
\hline & $\mathrm{Bt} 2$ & 12.9 & 33.6 & 53.4 & 52.4 & 8.0 & 0.3 & 42.8 & $\operatorname{Tr}$ & 0.68 & 23.6 & \\
\hline & $\mathrm{B}$ & 19.3 & 33.3 & 47.4 & 52.2 & 8.2 & 0.3 & 35.5 & $\operatorname{Tr}$ & 0.81 & 19.8 & \\
\hline \multirow[t]{3}{*}{45} & Ap & 17.3 & 44.0 & 38.7 & 60.6 & 7.7 & 0.5 & 52.0 & $\operatorname{Tr}$ & 1.64 & 24.4 & Calcic Haploxeralfs \\
\hline & Btk1 & 9.3 & 35.3 & 55.4 & 57.3 & 8.0 & 0.3 & 55.2 & $\operatorname{Tr}$ & 0.76 & 21.3 & \\
\hline & Btk2 & 12.9 & 31.6 & 55.4 & 52.9 & 8.3 & 0.3 & 53.1 & $\operatorname{Tr}$ & 0.61 & 19.1 & \\
\hline \multirow[t]{3}{*}{46} & Ap & 35.3 & 30.0 & 34.7 & 57.6 & 7.7 & 0.1 & 48.1 & $\operatorname{Tr}$ & 3.11 & 25.9 & Typic Haploxerolls \\
\hline & $\mathrm{C} 1$ & 45.3 & 23.3 & 31.4 & 51.2 & 7.9 & 0.2 & 45.4 & $\operatorname{Tr}$ & 0.79 & 25.1 & \\
\hline & $\mathrm{C} 2$ & 84.0 & 4.6 & 11.4 & 49.7 & 7.6 & 0.5 & 58.4 & $\operatorname{Tr}$ & 0.54 & 5.3 & \\
\hline \multirow[t]{2}{*}{47} & Ap & 56.9 & 19.6 & 23.4 & 34.0 & 8.0 & 0.6 & 65.9 & $\operatorname{Tr}$ & 0.65 & 9.9 & Typic Xerorthents \\
\hline & $\mathrm{C}$ & 58.0 & 19.3 & 22.7 & 32.3 & 8.0 & 0.6 & 67.8 & $\operatorname{Tr}$ & 0.51 & 9.4 & \\
\hline \multirow[t]{3}{*}{49} & Ap & 32.0 & 32.6 & 35.4 & 34.4 & 8.0 & 0.7 & 32.3 & $\operatorname{Tr}$ & 2.27 & 25.1 & Calcic Haploxeralfs \\
\hline & Bt1 & 25.3 & 33.3 & 41.4 & 48.4 & 8.1 & 0.3 & 59.6 & $\operatorname{Tr}$ & 0.65 & 18.4 & \\
\hline & $\mathrm{Bt} 2 \mathrm{k}$ & 27.3 & 29.3 & 43.4 & 40.5 & 7.6 & 0.3 & 35.5 & $\operatorname{Tr}$ & 0.78 & 22.8 & \\
\hline \multirow[t]{3}{*}{51} & Ap & 15.3 & 38.0 & 46.7 & 51.5 & 8.0 & 0.2 & 20.2 & $\operatorname{Tr}$ & 0.88 & 30.1 & Mollic Haploxeralfs \\
\hline & Bt1 & 11.3 & 31.3 & 57.4 & 36.1 & 7.8 & 0.3 & 8.1 & $\operatorname{Tr}$ & 1.16 & 35.3 & \\
\hline & $\mathrm{Bt} 2$ & 21.3 & 28.0 & 50.7 & 39.1 & 8.2 & 0.6 & 29.7 & $\operatorname{Tr}$ & 0.52 & 23.6 & \\
\hline \multirow[t]{3}{*}{52} & Ap & 35.3 & 39.3 & 25.4 & 53.6 & 7.8 & 0.5 & 47.8 & $\operatorname{Tr}$ & 1.16 & 25.1 & Calcic Haploxeralfs \\
\hline & Btk & 23.3 & 26.0 & 50.7 & 40.3 & 8.0 & 0.4 & 41.2 & $\operatorname{Tr}$ & 0.14 & 24.4 & \\
\hline & $\mathrm{Ck}$ & 34.9 & 21.6 & 43.4 & 43.2 & 8.2 & 0.2 & 45.4 & $\operatorname{Tr}$ & 0.14 & 18.4 & \\
\hline \multirow[t]{3}{*}{53} & A & 39.3 & 26.0 & 34.7 & 40.7 & 7.9 & 2.1 & 22.6 & $\operatorname{Tr}$ & 1.37 & 21.3 & Typic Xerorthents \\
\hline & $\mathrm{C} 1$ & 78.0 & 8.6 & 13.4 & 50.9 & 7.6 & 1.0 & 82.8 & $\operatorname{Tr}$ & 0.20 & 5.5 & \\
\hline & $\mathrm{C} 2$ & 83.3 & 8.0 & 8.7 & 22.5 & 7.4 & 1.6 & 79.6 & $\operatorname{Tr}$ & 0.20 & 3.5 & \\
\hline \multirow[t]{2}{*}{54} & Ap & 12.0 & 36.6 & 51.4 & 58.8 & 7.9 & 0.5 & 47.3 & $\operatorname{Tr}$ & 1.03 & 16.3 & Typic Xerorthents \\
\hline & $\mathrm{C}$ & 57.3 & 20.0 & 22.7 & 50.0 & 7.6 & 0.8 & 57.0 & $\operatorname{Tr}$ & 0.85 & 10.5 & \\
\hline
\end{tabular}

Note: SP, saturation percentage; EC, electrical conductivity; CCE: calcium carbonate equivalent; OC, organic carbon; CEC, cation exchangeable capacity; Tr, trace. A, surface horizon; B, subsoil; C, substratum; A/B, transitional horizon; $\mathrm{k}$, accumulation of secondary carbonates; $\mathrm{p}$, tillage or other disturbance; $\mathrm{w}$, development of color or structure; $\mathrm{y}$, accumulation of gypsum; $\mathrm{t}$, accumulation of silicate clay; g, strong gleying; r, weathered or soft bedrock; ss, presence of slickensides; II, lithologic discontinuities. Numerical suffixes (i.e., $1,2,3$ ) are used to denote subdivisions within a master horizon (e.g., Bk1, Bk2). 
horizon were classified into Calcidic Haplustalfs, Calcic Haploxeralfs, Mollic Haploxeralfs, Calcidic Argiustolls and Pachic Argixerolls. The forming processes of these soils mainly occur in piedmont plains and plateaus. Due to high precipitation, these soils are less calcareous, especially in the east and northeast of the province. Because of highly calcareous parent materials and low precipitation in the west and south of the study area, the main horizon is calcic, with accumulation of nodules and powdery pockets of carbonate (pedons 2, 3, 5, 7, 23, 26, 33 and 35 in the western and southern regions and pedons 49 and 52 in the eastern region). Gypsic horizon was found only in the driest area near Gachsaran geological formation (formation with high gypsum content), such as pedons 12, 13 and 15. Cambic horizon was seen as the ordinary horizon in poor developed soils like Inceptisols (Pedon 30) and Mollisols (pedons 1 and 36). Ochric epipedon occurred in all soils of the study area with an exception of Mollisols. Mollic epipedon in pedons 1, 2, 36, 38, and 46 had high OC content and developed structure. Entisols are soils without developed horizon that have been spread in alluvial plains and alluvial fans in all regions.

Most of the soils were loamy with heavy texture, especially Alfisols, while almost all Entisols contained more sand and were coarse-textured. All soils except those pedons (pedons 38, 39, 40, 42 and 51) that occurred in the region with high precipitation were highly calcareous with average calcium carbonate $\left(\mathrm{CaCO}_{3}\right)$ content being higher than $40 \%$. Since the variation in CEC of soils is mostly related to the content and type of clay and $\mathrm{OC}$, as a result of increasing in precipitation and weathering in soils in the east and north of Kohgiluyeh and Boyer-Ahmad Province, CEC was higher in these regions than in other regions. According to the results, there was no difference in OC content between humid and arid regions. The OC content was reduced in more humid areas mainly due to intensive agriculture. In addition, the value of EC was low in almost all soils with an exception of gypsic soil.

\subsection{Soil mineralogy}

Relative abundance of clay fractions in the studied soils is shown in Table 2. Smectite, chlorite, illite, palygorskite, vermiculite, kaolinite and interstratified illite-smectite were the dominant clay minerals in the clay samples. The main clay minerals were illite, chlorite and palygorskite in the west and south of Kohgiluyeh and Boyer-Ahmad Province, whereas they were smectite, vermiculite and illite in the north and east of the province. Although illite and chlorite were found in almost all surface and subsurface pedons, they were the major clay minerals in low developed pedons of steep relief, alluvial deposit and regions with low precipitation. In almost all pedons (except some Entisoils), illite mineral showed a decreasing trend with increasing depth, mostly due to the enriched sources of illite from the surrounding areas. Because of the inheritance origin and transportation of illite by erosion and aeolian to surface soils, and also the alteration from biotite in surface soils due to daily and seasonal variations in moisture and temperature, illite decreased with increasing soil depth (Khormali and Abtahi, 2003). Alteration of illite to smectite occurred mostly in surface soils of Alfisols and other soils in humid regions, and since smectite was present in fine fraction, therefore contrary to illite, it moved and deposited into the subsurface horizon. Chlorite showed an independent behavior with soil depth and climate. Illite and chlorite are of hereditary origin. Kaolinite occurred in tropical conditions and its origin in the study area was inherited from the surrounding formations and sediments. Except for pedons 12, 13, 15, 17, 46, 47 and 49 which were derived from Gachsaran formation (the most important cap rock of hydrocarbon reservoir in Iran and has important deposits of salt, sulfur and gypsum), other pedons have shown some kaolinite in their clay fraction.

Owliaie et al. (2006) reported that the presence of illite, chlorite and kaolinite in some calcareous soils of Iran has an inherited origin. Smectite was the main clay mineral in the north and east of Kohgiluyeh and Boyer-Ahmad Province, and also in some pedons in the northwest. Since all pedons (with an exception of Pedon 40) were well drained, therefore transformation should be the main process for smectite formation. Sufficient precipitation, especially in the north and east, caused a release of $\mathrm{K}$ from illite, therefore the high soil $\mathrm{pH}$ and abundance of $\mathrm{Mg}$ resulted in the formation of smectite. In addition, some areas have long winters (high precipitation and moderate temperature), as a result, neoformation also occurred in soils. In some pedons of 
arid and semi-arid regions, near the formations with marl parent materials, detrital origin is the dominant reason for the presence of smectite. Khormali and Abtahi (2003) revealed that soil available moisture is the most important factor that determines the distribution of smectite and palygorskite in arid and semi-arid regions.

Table 2 Semi-quantitative analysis of soil clay content in the studied pedons

\begin{tabular}{|c|c|c|c|c|c|c|c|c|c|}
\hline Pedon & Soil sample No. & Horizon & Sme & Ill & Chl & Ver & Kao & Pal & Mixed layer \\
\hline \multirow[t]{2}{*}{1} & 1 & Ap & +++ & +++ & ++ & + & + & ++ & + Ill-Sme \\
\hline & 2 & Bw1 & +++ & ++ & ++ & + & + & ++ & + Ill-Sme \\
\hline \multirow[t]{2}{*}{2} & 3 & Ap & +++ & +++ & ++ & + & + & ++ & ++ Ill-Sme \\
\hline & 4 & $\mathrm{~A} / \mathrm{B}$ & +++ & ++ & +++ & + & + & ++ & ++ Ill-Sme \\
\hline \multirow[t]{2}{*}{3} & 5 & Ap & +++ & +++ & + & + & + & ++ & + Ill-Sme \\
\hline & 6 & Bk1 & ++ & ++ & + & + & + & ++ & + Ill-Sme \\
\hline \multirow[t]{2}{*}{5} & 7 & Ap & +++ & +++ & + & + & + & ++ & - \\
\hline & 8 & Bk1 & ++ & +++ & + & + & + & ++ & - \\
\hline \multirow[t]{2}{*}{7} & 9 & Ap & +++ & +++ & ++ & + & ++ & ++ & - \\
\hline & 10 & Btk1 & +++ & ++ & + & + & ++ & ++ & - \\
\hline \multirow[t]{2}{*}{11} & 11 & Ap & ++ & ++ & ++ & + & ++ & + & - \\
\hline & 12 & $\mathrm{C} 1$ & ++ & +++ & ++ & + & ++ & ++ & - \\
\hline \multirow[t]{2}{*}{12} & 13 & Ap & + & ++ & +++ & - & - & +++ & - \\
\hline & 14 & By1 & + & ++ & ++ & - & - & ++++ & - \\
\hline \multirow[t]{2}{*}{13} & 15 & Ap & + & +++ & ++ & - & - & +++ & - \\
\hline & 16 & By & + & ++ & ++ & - & - & ++++ & - \\
\hline \multirow[t]{2}{*}{15} & 17 & Ap & ++ & +++ & ++ & - & - & +++ & - \\
\hline & 18 & $\mathrm{C} 1$ & ++ & ++ & ++ & - & - & ++++ & - \\
\hline \multirow[t]{2}{*}{17} & 19 & Ap & ++ & +++ & ++ & - & - & +++ & - \\
\hline & 20 & $\mathrm{C} 1$ & ++ & ++ & ++ & - & - & ++++ & - \\
\hline \multirow[t]{2}{*}{21} & 21 & $\mathrm{~A}$ & +++ & ++ & ++ & - & + & ++ & - \\
\hline & 22 & $\mathrm{Cg}$ & ++ & ++ & ++ & - & + & +++ & - \\
\hline \multirow[t]{2}{*}{23} & 23 & Ap & +++ & +++ & ++ & - & + & +++ & - \\
\hline & 24 & Btk1 & +++ & ++ & - & - & + & ++++ & - \\
\hline \multirow[t]{2}{*}{26} & 25 & Ap & +++ & ++ & - & - & + & + & - \\
\hline & 26 & Bk1 & +++ & + & - & - & + & + & - \\
\hline \multirow[t]{2}{*}{29} & 27 & Ap & +++ & + & ++ & + & + & + & - \\
\hline & 28 & $\mathrm{C} 1$ & + & ++ & ++ & - & ++ & ++ & - \\
\hline \multirow[t]{2}{*}{30} & 29 & Ap & +++ & + & - & ++ & + & + & - \\
\hline & 30 & Bw1 & +++ & + & - & ++ & + & ++ & - \\
\hline \multirow[t]{2}{*}{33} & 31 & Ap & +++ & ++ & ++ & + & + & ++ & - \\
\hline & 32 & Btk1 & +++ & + & ++ & - & + & ++ & - \\
\hline \multirow[t]{2}{*}{34} & 33 & Ap & ++++ & + & - & - & + & + & - \\
\hline & 34 & $\mathrm{C} 1$ & ++++ & + & + & + & + & + & - \\
\hline \multirow[t]{2}{*}{35} & 35 & Ap & +++ & ++ & - & + & + & + & ++ Ill-Sme \\
\hline & 36 & Bk1 & ++++ & + & - & - & + & + & + Ill-Sme \\
\hline \multirow[t]{2}{*}{36} & 37 & Ap & +++ & ++ & ++ & + & ++ & - & - \\
\hline & 38 & $\mathrm{Bw}$ & +++ & ++ & ++ & - & ++ & - & - \\
\hline \multirow[t]{2}{*}{38} & 39 & Ap & ++++ & ++ & + & ++ & + & - & - \\
\hline & 40 & Bt1 & ++++ & + & - & ++ & + & - & - \\
\hline \multirow[t]{2}{*}{39} & 41 & Ap & +++ & ++ & + & ++ & + & - & ++ Ill-Sme \\
\hline & 42 & Bkss & +++ & + & ++ & + & ++ & - & - \\
\hline
\end{tabular}




\begin{tabular}{|c|c|c|c|c|c|c|c|c|c|}
\hline Pedon & Soil sample No. & Horizon & Sme & Ill & Chl & Ver & Kao & Pal & Mixed layer \\
\hline \multirow[t]{2}{*}{40} & 43 & Ap & ++++ & + & + & + & ++ & + & ++ Ill-Sme \\
\hline & 44 & $\mathrm{Bg} 1$ & ++++ & - & - & + & ++ & - & ++ Ill-Sme \\
\hline \multirow[t]{2}{*}{42} & 45 & Ap & +++ & + & + & +++ & + & - & + Ill-Sme \\
\hline & 46 & Bt1 & ++++ & + & + & ++ & + & - & + Ill-Sme \\
\hline \multirow[t]{2}{*}{44} & 47 & Ap & ++++ & - & - & ++ & + & - & + Ill-Sme \\
\hline & 48 & Bt1 & ++++ & - & - & ++ & + & - & - \\
\hline \multirow[t]{2}{*}{45} & 49 & Ap & ++++ & + & + & ++ & ++ & - & + Ill-Sme \\
\hline & 50 & Btk1 & ++++ & - & - & ++ & + & - & ++ Ill-Sme \\
\hline \multirow[t]{2}{*}{46} & 51 & Ap & +++ & ++ & ++ & ++ & - & ++ & + Ill-Sme \\
\hline & 52 & $\mathrm{C} 1$ & ++ & ++ & +++ & ++ & - & - & + Ill-Sme \\
\hline \multirow[t]{2}{*}{47} & 53 & Ap & +++ & ++ & ++ & ++ & - & + & - \\
\hline & 54 & $\mathrm{C}$ & +++ & ++ & ++ & + & - & ++ & - \\
\hline \multirow[t]{2}{*}{49} & 55 & Ap & ++ & +++ & +++ & ++ & - & - & - \\
\hline & 56 & Bt1 & ++ & + & ++++ & + & - & ++ & - \\
\hline \multirow[t]{2}{*}{51} & 57 & Ap & ++++ & +++ & - & ++ & ++ & - & - \\
\hline & 58 & Bt1 & +++ & ++ & - & +++ & + & - & - \\
\hline \multirow[t]{2}{*}{52} & 59 & Ap & +++ & ++ & - & ++ & + & ++ & - \\
\hline & 60 & Btk & ++++ & + & - & ++ & + & + & - \\
\hline \multirow[t]{2}{*}{53} & 61 & A & +++ & + & +++ & - & ++ & + & - \\
\hline & 62 & $\mathrm{C} 1$ & ++ & ++ & +++ & + & ++ & ++ & - \\
\hline \multirow[t]{2}{*}{54} & 63 & Ap & ++ & +++ & + & + & + & +++ & - \\
\hline & 64 & $\mathrm{C}$ & + & +++ & ++ & - & + & ++ & - \\
\hline
\end{tabular}

Note: Sme, smectite; Ill, illite; Chl, chlorite; Ver, vermiculite; Kao, kaolinite; Pal, palygorskite; Ill-Sme, illite-smectite; -, trace or not detected; + , content $<15 \%$; ++, content in the range of $15 \%-30 \% ;+++$, content in the range of $30 \%-50 \%$; ++++, content $>50 \%$.

In arid and semi-arid regions, there was a correlation between smectite and palygorskite with respect to soil available moisture. Vermiculite is a rare clay mineral in the study area. Considering the fact that the acidity of soils in the study area is more than 7 and aluminum is not soluble in these soils, as well as high levels of $\mathrm{Mg}$ in the soil solution, we therefore conclude that vermiculite is less stable in the study area. Palygorskite was the dominant clay in arid and semi-arid regions. The main mineral in Gypsic horizon and almost all pedons with calcic horizon was palygorskite (Fig. 3). High specific surface area and high $\mathrm{Mg}$ content were the most important properties for this fibrous mineral. Inherence from parent materials and pedogenic formation were the two origins for the existence of palygorskite in the study area. Pedogenic palygorskite can originate from in situ transformation of other minerals such as smectite in arid and semi-arid regions (Khormali and Abtahi, 2003) or from authigenic formation of soil solution (Xie et al., 2013). Parent rocks and deposit by water and wind erosion can add palygorskite to soils in regions lacking normal conditions for palygorskite formation (Khademi and Mermut, 1998).

\subsection{Potassium (K) forms}

Amounts of different $\mathrm{K}$ forms (soluble, exchangeable, non-exchangeable and structural) in surface and subsurface soils are shown in Table 3. As can be seen, soluble $\mathrm{K}$ varied from 0.4 to $36.0 \mathrm{mg} / \mathrm{kg}$ (average of $4.2 \mathrm{mg} / \mathrm{kg}$ ) in surface soils and 0.2 to $11.0 \mathrm{mg} / \mathrm{kg}$ (average of $1.8 \mathrm{mg} / \mathrm{kg}$ ) in subsurface soils. Exchangeable K ranged from 98 to $709 \mathrm{mg} / \mathrm{kg}$ (average of $211 \mathrm{mg} / \mathrm{kg}$ ) and 27 to $438 \mathrm{mg} / \mathrm{kg}$ (average of $129 \mathrm{mg} / \mathrm{kg}$ ) in surface and subsurface soils, respectively. Non-exchangeable K was in the range of 230-956 mg/kg (average of $418 \mathrm{mg} / \mathrm{kg}$ ) in surface soils and $80-892 \mathrm{mg} / \mathrm{kg}$ (average of $295 \mathrm{mg} / \mathrm{kg}$ ) in subsurface soils. Amounts of structural K varied from 3458 to $9108 \mathrm{mg} / \mathrm{kg}$ (average of $5723 \mathrm{mg} / \mathrm{kg}$ ) in surface soils and 1993 to $10,494 \mathrm{mg} / \mathrm{kg}$ (average of $5507 \mathrm{mg} / \mathrm{kg}$ ) in subsurface soils. Correlation coefficients between soil $\mathrm{K}$ forms 


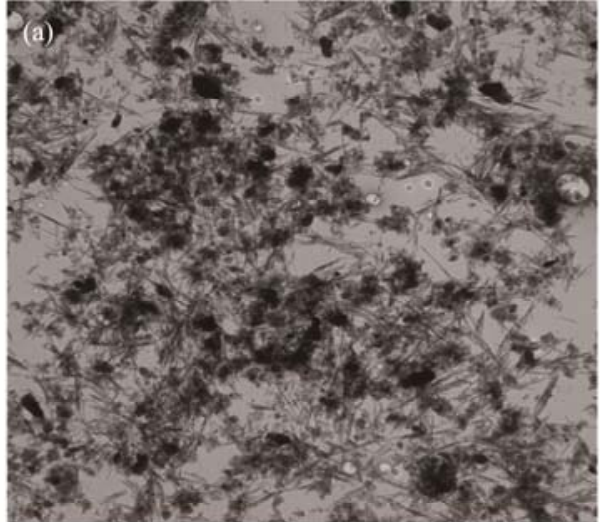

$1 \mu \mathrm{m}$

1450

(c)

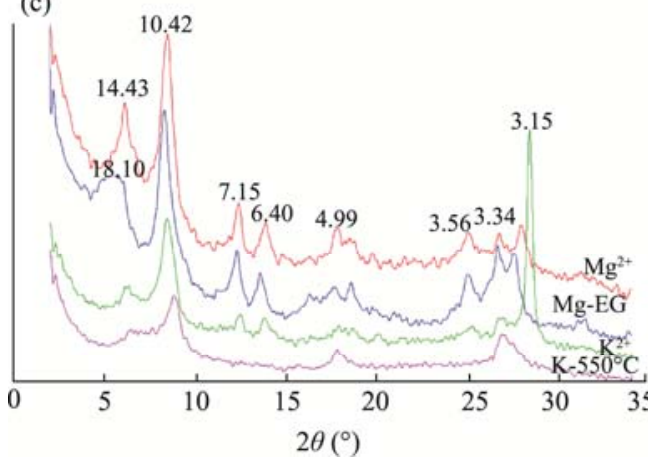

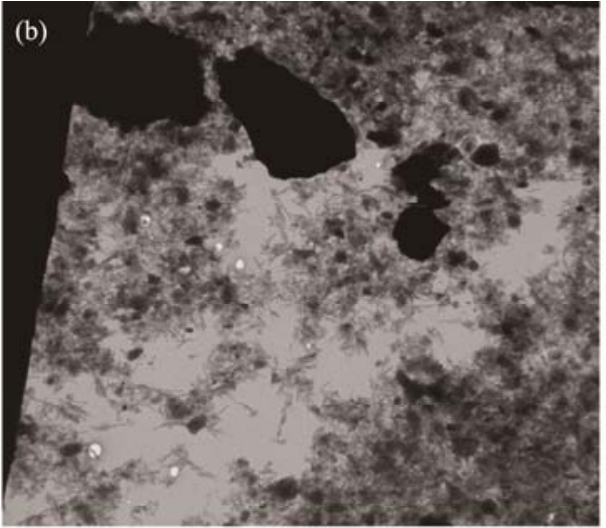

$1 \mu \mathrm{m}$

$1450 \times$

(d)

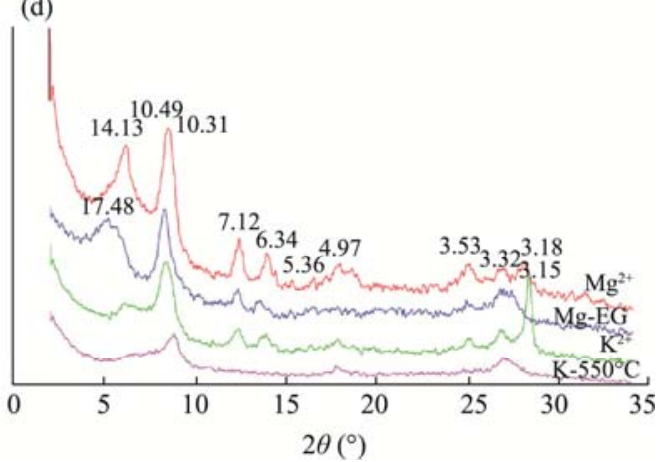

Fig. 3 TEM (Transmission electron microscope) images of clay in (a) By horizon of Pedon 14 and (b) Bk horizon of Pedon 23 showing palygorskite fibres, and XRD (X-ray diffraction) patterns of clay in (c) By horizon of Pedon 14 and (d) Bk horizon of Pedon 23. B, subsoil; y, accumulation of gypsum; k, accumulation of secondary carbonates. The meaning of $1450 \times$ is magnifying 1450 by microscope. Mg-EG, Mg-ethylene glycol.

(soluble, exchangeable, non-exchangeable and structural), clay minerals (including illite, smectite, vermiculite and smectite+vermiculite) and physical-chemical properties (including CEC, clay, OC and CCE) are given in Table 4.

\subsubsection{Soluble and exchangeable $\mathrm{K}$}

The results in Tables 3 and 4 showed that soluble $\mathrm{K}$ varied in pedons, although it was higher in surface soils than in subsurface soils and was significantly correlated with OC and exchangeable $\mathrm{K}$ (Pearson correlation coefficients of 0.465 and 0.468 , respectively). Soluble $\mathrm{K}$ did not show significant correlation with other soil physical-chemical properties (CEC, clay content and CCE), clay minerals (illite, smectite, vermiculite and smectite+vermiculite), and other two $\mathrm{K}$ forms (non-exchangeable and structural). Soluble $\mathrm{K}$ can be affected by $\mathrm{K}$ fertilizers, plant uptake, replacement by other $\mathrm{K}$ forms, and sampling time. There are several $\mathrm{K}$ minerals in soils, but availability of the $\mathrm{K}$ soluble form for plant growth is usually limited (Hayashi et al., 2014). Soluble $\mathrm{K}$ was the smallest part of total $\mathrm{K}$ in surface and subsurface soils (accounting for $0.1 \%$ of total $\mathrm{K}$ ). In the study area, exchangeable $\mathrm{K}$ accounted for $3.3 \%$ of total $\mathrm{K}$ in surface soils and $2.2 \%$ in subsurface soils. Exchangeable $\mathrm{K}$ was higher in surface soils than in subsurface soils. The largest amount of exchangeable $\mathrm{K}$ in the study area was in surface soils of pedons 36 (Mollisols), 49 (Alfisols), 33 (Alfisols), 46 (Mollisols), 2 (Mollisols) and 39 (Vertisols). In these pedons, OC content was high and smectite was a predominant mineral. In addition, lower amount of exchangeable K was found in subsurface soils of pedons 7 (Alfisols), 29 (Entisols), 53 (Entisols), 13 (Inceptisols), 30 (Inceptisols), 11 (Entisols) and 12 (Inceptisols). These results revealed that poor-developed soils, except pedon 7 due to the presence of Gachsaran formation (palygorskite as 
Table 3 Amounts of different $\mathrm{K}$ forms and cumulative non-exchangeable $\mathrm{K}$ released in different media of extraction in representative pedons

\begin{tabular}{|c|c|c|c|c|c|c|c|c|c|c|c|c|}
\hline \multirow{4}{*}{ Pedon } & \multirow{2}{*}{\multicolumn{2}{|c|}{ Soluble K }} & \multirow{2}{*}{\multicolumn{2}{|c|}{ Exchangeable K }} & \multirow{2}{*}{\multicolumn{2}{|c|}{ Non-exchangeable $\mathrm{K}$}} & \multirow{2}{*}{\multicolumn{2}{|c|}{ Structural K }} & \multicolumn{4}{|c|}{ Cumulative non-exchangeable $\mathrm{K}$} \\
\hline & & & & & & & & & \multicolumn{2}{|c|}{$0.01 \mathrm{M} \mathrm{CaCl}_{2}$} & \multicolumn{2}{|c|}{$0.01 \mathrm{M}$ oxalic acid } \\
\hline & SurS & SubS & SurS & SubS & SurS & SubS & SurS & SubS & SurS & SubS & SurS & SubS \\
\hline & \multicolumn{12}{|c|}{$(\mathrm{mg} / \mathrm{kg})$} \\
\hline 1 & 2.5 & 7.0 & 122 & 77 & 280 & 148 & 3889 & 1993 & 231 & 183 & 201 & 145 \\
\hline 2 & 3.0 & 0.8 & 288 & 161 & 515 & 326 & 6380 & 5930 & 276 & 232 & 246 & 217 \\
\hline 3 & 3.4 & 11.0 & 251 & 148 & 446 & 365 & 6001 & 5988 & 240 & 224 & 220 & 200 \\
\hline 5 & 1.0 & 0.4 & 122 & 73 & 251 & 255 & 4597 & 4730 & 153 & 144 & 135 & 118 \\
\hline 7 & 1.1 & 0.2 & 110 & 27 & 244 & 161 & 3855 & 3696 & 147 & 149 & 142 & 131 \\
\hline 11 & 2.7 & 0.3 & 155 & 62 & 326 & 175 & 3727 & 3809 & 192 & 151 & 171 & 136 \\
\hline 12 & 3.5 & 0.7 & 129 & 67 & 329 & 349 & 4167 & 4468 & 160 & 135 & 148 & 129 \\
\hline 13 & 4.9 & 2.1 & 116 & 44 & 237 & 188 & 4102 & 4225 & 157 & 121 & 152 & 113 \\
\hline 15 & 1.9 & 2.2 & 110 & 79 & 280 & 168 & 3818 & 4896 & 146 & 129 & 134 & 117 \\
\hline 17 & 36.0 & 3.3 & 181 & 85 & 266 & 213 & 4751 & 5288 & 154 & 169 & 148 & 151 \\
\hline 21 & 4.9 & 1.8 & 179 & 73 & 251 & 181 & 5517 & 4889 & 157 & 138 & 153 & 132 \\
\hline 23 & 1.4 & 2.0 & 104 & 142 & 273 & 155 & 3668 & 3111 & 144 & 126 & 129 & 121 \\
\hline 26 & 2.1 & 0.3 & 216 & 102 & 405 & 266 & 7564 & 6525 & 210 & 167 & 189 & 152 \\
\hline 29 & 3.8 & 0.4 & 195 & 39 & 455 & 98 & 5116 & 2230 & 166 & 111 & 174 & 117 \\
\hline 30 & 0.9 & 0.3 & 116 & 56 & 230 & 175 & 3458 & 3414 & 151 & 168 & 153 & 158 \\
\hline 33 & 6.2 & 4.8 & 396 & 175 & 699 & 421 & 7815 & 6979 & 305 & 214 & 296 & 203 \\
\hline 34 & 1.2 & 0.7 & 251 & 85 & 381 & 142 & 6164 & 2951 & 257 & 136 & 234 & 139 \\
\hline 35 & 1.4 & 0.2 & 244 & 71 & 446 & 251 & 5538 & 4391 & 259 & 188 & 243 & 169 \\
\hline 36 & 28.0 & 0.9 & 709 & 216 & 690 & 389 & 6354 & 6192 & 513 & 215 & 488 & 198 \\
\hline 38 & 0.4 & 0.2 & 116 & 157 & 455 & 373 & 6909 & 7110 & 236 & 211 & 197 & 165 \\
\hline 39 & 1.2 & 0.2 & 273 & 181 & 541 & 489 & 8314 & 9328 & 265 & 193 & - & - \\
\hline 40 & 0.9 & 2.9 & 155 & 161 & 405 & 515 & 9108 & 9320 & 213 & 215 & - & - \\
\hline 42 & 1.1 & 0.6 & 223 & 116 & 497 & 421 & 6464 & 7751 & 243 & 210 & 212 & 173 \\
\hline 44 & 1.4 & 0.6 & 195 & 163 & 387 & 532 & 5277 & 5440 & 239 & 234 & 209 & 206 \\
\hline 45 & 2.4 & 0.8 & 266 & 280 & 303 & 230 & 4057 & 4374 & 246 & 231 & 231 & 208 \\
\hline 46 & 7.6 & 2.3 & 310 & 295 & 492 & 209 & 5607 & 7578 & 261 & 241 & 228 & 221 \\
\hline 47 & 1.1 & 0.5 & 104 & 73 & 326 & 148 & 5338 & 4663 & 150 & 139 & 131 & 129 \\
\hline 49 & 2.4 & 0.5 & 405 & 142 & 680 & 463 & 8256 & 7788 & 307 & 203 & 249 & 180 \\
\hline 51 & 0.4 & 1.2 & 202 & 438 & 956 & 892 & 8185 & 10,494 & 292 & 344 & 247 & - \\
\hline 52 & 2.6 & 3.7 & 268 & 199 & 446 & 318 & 5984 & 5896 & 298 & 259 & 267 & 231 \\
\hline 53 & 0.7 & 2.3 & 98 & 39 & 489 & 80 & 6598 & 3524 & 252 & 109 & 233 & 89 \\
\hline 54 & 1.3 & 2.6 & 142 & 91 & 389 & 341 & 6555 & 7245 & 193 & 145 & 172 & 129 \\
\hline Mean & 4.2 & 1.8 & 211 & 129 & 418 & 295 & 5723 & 5507 & 225 & 182 & 204 & 158 \\
\hline
\end{tabular}

Note: SurS, surface soil; SubS, subsurface soil; -, no data.

the predominant mineral), had less exchangeable $\mathrm{K}$. In these soils, the main minerals were illite, chlorite, and palygorskite. The relationship between different forms of $\mathrm{K}$ is generally influenced by the type of clay and soil texture (Nabiollahy et al., 2006). Moreover, exchangeable $\mathrm{K}$ is retained by expanding clay minerals (Sharpley, 1989). Bhonsle et al. (1992) reported that the largest amount of exchangeable $\mathrm{K}$ is in soils with smectite as the main mineral. Exchangeable $\mathrm{K}$ is held throughout electrostatic charges present on organic matter and clay particles (Conyers and McLean, 1969). Enriched sources of illite in the surrounding areas and alteration of biotite in surface soils due to daily and seasonal variations of moisture and temperature resulted in illite decreased with increasing soil depth (Khormali and Abtahi, 2003). Alteration of illite to smectite occurred in surface soils of Alfisols and other soils in humid regions. Compared to illite, smectite 
can be transformed and deposited into subsurface soils because smectite is in fine fraction, but the major reason could be due to the presence of a lot of smectite in parent materials which increases with increasing soil depth.

Exchangeable $\mathrm{K}$ was significantly correlated with OC, CEC, CCE, illite, smectite and vermiculite (Pearson correlation coefficients of $0.784,0.663,-0.474,0.293,0.263$ and 0.313 , respectively; Table 4). Due to more smectite and high OC content in surface soils, the amount of exchangeable $\mathrm{K}$ in surface soils was higher than that in subsurface soils. The high correlations of exchangeable $\mathrm{K}$ with $\mathrm{OC}$ and $\mathrm{CEC}$ referred especially to the organic matter and clay surface, which are able to absorb and exchange $\mathrm{K}$ in soils. It seems that organic matter plays a more important role than smectite mineral in retaining exchangeable $\mathrm{K}$ in the studied soils. Raheb and Heidari (2012) stated that the smectitic soils are rich in exchangeable K, whereas the predominant illite soils exhibit low amount of exchangeable $\mathrm{K}$. In addition, there are significant correlations of exchangeable $\mathrm{K}$ with $\mathrm{CEC}$ and $\mathrm{OC}$.

Table 4 Pearson correlation coefficients between soil $\mathrm{K}$ forms, clay minerals and physical-chemical properties

\begin{tabular}{|c|c|c|c|c|c|c|c|c|c|c|c|}
\hline & Sol & Exc & Non-exc & Str & CEC & $\mathrm{OC}$ & Clay & CCE & Ill & Sme & Ver \\
\hline Exc & $0.468^{* *}$ & & & & & & & & & & \\
\hline Non-exc & 0.135 & $0.476^{* *}$ & & & & & & & & & \\
\hline Str & 0.024 & $0.321^{*}$ & $0.757^{* *}$ & & & & & & & & \\
\hline CEC & 0.074 & $0.663^{* *}$ & $0.441^{* *}$ & $0.543^{* *}$ & & & & & & & \\
\hline $\mathrm{OC}$ & $0.465^{* *}$ & $0.784^{* *}$ & $0.277^{*}$ & 0.163 & $0.580^{* *}$ & & & & & & \\
\hline Clay & -0.223 & 0.218 & $0.290^{*}$ & $0.506^{* *}$ & $0.612^{* *}$ & 0.097 & & & & & \\
\hline $\mathrm{CCE}$ & 0.111 & $-0.474^{* *}$ & $-0.447^{* *}$ & $-0.572^{* *}$ & $-0.776^{* *}$ & $-0.361^{* *}$ & $-0.557^{* *}$ & & & & \\
\hline Ill & -0.061 & $0.293^{*}$ & $0.361^{* *}$ & $0.301^{*}$ & $0.362^{* *}$ & 0.153 & $0.512^{* *}$ & $-0.472^{* *}$ & & & \\
\hline Sme & -0.191 & $0.263^{*}$ & $0.324^{*}$ & $0.552^{* *}$ & $0.672^{* *}$ & 0.058 & $0.770^{* *}$ & $-0.466^{* *}$ & $0.264^{*}$ & & \\
\hline Ver & -0.151 & $0.313^{*}$ & $0.373^{* *}$ & $0.509^{* *}$ & $0.696^{* *}$ & 0.153 & $0.580^{* *}$ & $-0.506^{* *}$ & $0.329^{*}$ & $0.754^{* *}$ & \\
\hline Sme+Ver & -0.187 & $0.299^{*}$ & $0.364^{* *}$ & $0.569^{* *}$ & $0.724^{* *}$ & 0.099 & $0.743^{* *}$ & $-0.512^{* *}$ & $0.307^{*}$ & $0.965^{* *}$ & $0.900^{* *}$ \\
\hline
\end{tabular}

Note: ${ }^{*}$, significance at $P<0.05$ level; ${ }^{* *}$, significance at $P<0.01$ level. Sol, soluble K; Exc, exchangeable K; Non-exc, non-exchangeable $\mathrm{K}$; Str, structural K; CEC, cation exchangeable capacity; OC, organic carbon; CCE, calcium carbonate equivalent; Ill, illite; Sme, smectite; Ver, vermiculite.

\subsubsection{Non-exchangeable and structural K}

Non-exchangeable $\mathrm{K}$ can be calculated through subtraction of exchangeable $\mathrm{K}$ extracted by $1 \mathrm{M}$ $\mathrm{NH}_{4} \mathrm{OAc}$ solution from the experimental amount of extractable $\mathrm{K}$ by nitric acid. Non-exchangeable $\mathrm{K}$ is different from structural (mineral) $\mathrm{K}$. This form of $\mathrm{K}$, against the structural $\mathrm{K}$, is trapped in the tetrahedral layers of 2:1 minerals such as illite and vermiculite (Sparks, 2000). Similar to exchangeable K, the non-exchangeable K in the study area was also higher in surface soils than in subsurface soils and was significantly correlated with illite (Pearson correlation coefficient of 0.361$)$, vermiculite (0.373), smectite (0.324), clay content (0.290), CEC (0.441), OC (0.277) and CCE (-0.447) (Table 4). Raheb and Heidari (2012) found that due to the thermal and moisture conditions for weathering of primary minerals, the exchangeable and non-exchangeable $\mathrm{K}$ contents in surface soils were higher than those in subsurface soils. In the study area, some representative pedons such as 51 (Alfisols), 33 (Alfisols), 36 (Molisols), 49 (Alfisols) and 39 (Vertisols) had the larger amount of non-exchangeable $\mathrm{K}$ in surface soils (956, $699,690,680$ and $541 \mathrm{mg} / \mathrm{kg}$, respectively) and subsurface soils $(892,421,389,463$ and 541 $\mathrm{mg} / \mathrm{kg}$, respectively), while subsurface soils in the Entisols including pedons 53, 29, 34 and 47 had the lower amounts of non-exchangeable K. Alfisols in semi-arid regions are the most well-developed soils with moderate leaching. In the study area, Alfisols were the dominant soils because of high precipitation in the north and east in the present and past. High precipitation in these regions (northern and eastern parts) caused the leaching of $\mathrm{CaCO}_{3}$ from soil solum. Due to the enriched sources of $\mathrm{CaCO}_{3}$ from the surrounding areas (calcareous geology formations with more than $\left.90 \% \mathrm{CaCO}_{3}\right), \mathrm{CaCO}_{3}$ is added to soils in the study area recurrently. Consequently, low amount of vermiculite was found in the study area especially in surface soils, as well as moderate 
amount of illite, which is suggested to be due to water and wind erosion sediments from the surrounding mountains. Furthermore, high amount of smectite was found in the regions with high precipitation. The $\mathrm{CaCO}_{3}$ equivalent is an important influencing factor on the $\mathrm{K}$ forms. High significant negative correlation between $\mathrm{CCE}$ and non-exchangeable $\mathrm{K}$ revealed that a decrease in $\mathrm{CaCO}_{3}$ could cause increases in clay content and clay minerals. High clay content, smectites with different layer charges, and the presence of illite and vermiculite as large reserves of $\mathrm{K}$ are the reasons for the large amount of non-exchangeable $\mathrm{K}$ in these soils. This is consistent with the findings of Najafi Ghiri et al. (2010), who concluded that the amount of non-exchangeable $\mathrm{K}$ in soils with smectite as the mainly mineral is higher than that in soils with palygorskite and chlorite as the main minerals. Also, Hashemi and Abbaslou (2016) observed a significant correlation between non-exchangeable $\mathrm{K}$ and illite mineral in calcareous soils. Schindler et al. (2003) and Komadel et al. (2006) reported that the change of dioctahedral $\mathrm{Fe}^{3+}$ to $\mathrm{Fe}^{2+}$ contributes to the increase in $\mathrm{K}$ fixation in smectitic phyllosilicates. As a matter of fact, the strong interlayer forces, which ultimately result from $\mathrm{Fe}^{3+}$ reduction, may lead to layer collapses and thus trap interlayer cations such as $\mathrm{K}^{+}$. Low clay content, high CCE, poor-developed soil, and the presence of a large quantity of minerals containing less $\mathrm{K}$ like palygorskite, resulted in the small quantity of $\mathrm{K}$ in subsurface of Entisols in the study area. Zhan et al. (2014) stated that the differences of K fixation capacity in different soils may be related to the physical-chemical properties of soils such as CEC, clay content, $\mathrm{K}^{+}$saturation, and soil $\mathrm{K}$ content. Hosseinpur and Sinegani (2007) pointed out that the soils with heavy texture (clayey) and the soils with smectite as the predominant clay mineral have the largest quantity of non-exchangeable $\mathrm{K}$. The soils with 2:1 clay minerals such as high-layer-charge smectite, vermiculite and illite, contain larger quantity of non-exchangeable $\mathrm{K}$ than the soils with kaolinite as the main mineral (Ghosh and Singh, 2001).

In the study area, structural $\mathrm{K}$ in surface and subsurface soils accounted for $90.0 \%$ and $92.8 \%$ of total $\mathrm{K}$, respectively. It seems that these values may result from the fact that suitable conditions like temperature and humidity in surface soils for weathering cause more $\mathrm{K}$ to be released from primary and secondary minerals than the subsurface soils. Consequently, transformation in $\mathrm{K}$ reserve and translocation into deep soil depth contribute to less structural $\mathrm{K}$ in surface soils. Regarding parent rock and stage of soil development, structural K can constitute up to about $98 \%$ of total $\mathrm{K}$ in soils (Sparks and Huang, 1985). In the study area, pedons containing high structural $\mathrm{K}$ including 51 (Alfisols), 39 (Vertisols), 40 (Inceptisols), 49 (Alfisols), 42 (Alfisols) and 46 (Mollisols) are located in regions with high humidity. As shown in Table 4, structural $\mathrm{K}$ was significantly correlated with non-excha geable $\mathrm{K}$ (Pearson correlation coefficient of 0.757 ), exchangeable K (0.321), CEC (0.543), clay content (0.506), CCE (-0.572), illite (0.301), smectite $(0.552)$, vermiculite $(0.509)$ and smectite+vermiculite $(0.569)$. These results revealed that vermiculite, high-layer-charge smectite and illite play important roles in the high amount of structural K. Significant negative correlation of CCE with structural K in humid regions (pointed in non-exchangeable $\mathrm{K}$ ) resulted in increases of clay content and clay minerals in soils. Although the amount of illite was the same in almost all pedons in the study area, structural $\mathrm{K}$ was higher in humid regions than in arid and semi-arid regions. This difference may be related to the poor reservoir of $\mathrm{K}^{+}$minerals like palygorskite and chlorite accompanied by illite in arid and semi-arid regions. In humid regions, illite was accompanied by vermiculite and smectite as the $\mathrm{K}^{+}$reservoir.

\subsection{K released from clay minerals by $\mathrm{CaCl}_{2}$ and oxalic acid}

In this study, we evaluated the $\mathrm{K}$ released from clay minerals to calculate the amount of non-exchangeable $\mathrm{K}$ that can be released. Although non-exchangeable $\mathrm{K}$ is fixed, it can be released when exchangeable and soluble $\mathrm{K}$ is reduced through plant uptake or leaching. In calcareous soils, $\mathrm{Ca}^{2+}$ can be replaced by $\mathrm{K}^{+}$easier than others due to high quantity of $\mathrm{Ca}^{2+}$ in soil solution (Jalali, 2006). Also, $\mathrm{K}$ is weakly maintained compared to $\mathrm{Ca}^{2+}$, therefore $\mathrm{K}$ is more readily exchangeable than $\mathrm{Ca}^{2+}$ (Zhang et al., 2015). Oxalic acid is exuded by plant roots and causes weathering of minerals and $\mathrm{K}$ release. As the results, the mean amounts of non-exchangeable $\mathrm{K}^{+}$released from surface soils by $0.01 \mathrm{M} \mathrm{CaCl}_{2}$ and $0.01 \mathrm{M}$ oxalic acid were higher than those released from subsurface soils (Table 3). Specifically, $225 \mathrm{mg} / \mathrm{kg}$ 
non-exchangeable $\mathrm{K}$ was released from surface soils by $\mathrm{CaCl}_{2}$ and $182 \mathrm{mg} / \mathrm{kg}$ non-exchangeable $\mathrm{K}$ was released from subsurface soils by $\mathrm{CaCl}_{2}$; while $204 \mathrm{mg} / \mathrm{kg}$ non-exchangeable $\mathrm{K}$ was released from surface soils by oxalic acid and $158 \mathrm{mg} / \mathrm{kg}$ non-exchangeable $\mathrm{K}$ was released from subsurface soils by oxalic acid. Mean cumulative non-exchangeable $\mathrm{K}$ released by $\mathrm{CaCl}_{2}$ was higher than that released by oxalic acid. Oxalic acid can release $\mathrm{K}$ in soils by replacement or mineral destruction. Oxalic acid can be ionized as follows:
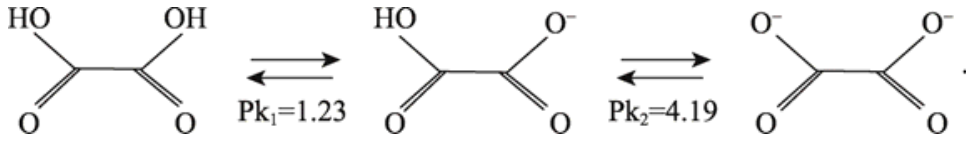

One $\mathrm{H}^{+}$ion and two $\mathrm{H}^{+}$ions are removed from oxalic acid at $\mathrm{pH}=3.5$ and $\mathrm{pH}>4.5$, respectively. In the study area, average soil $\mathrm{pH}$ is about 7.8 and oxalic acid separates to oxalate and $\mathrm{H}^{+}$ions. In calcareous soils, there are abundant $\mathrm{Ca}^{2+}$ and $\mathrm{OH}^{-}$ions, so when oxalic acid is added to calcareous soils (the reaction function below), the $\mathrm{OH}^{-}$ions in soil solution are neutralized by the $\mathrm{H}^{+}$ions liberated by the oxalic acid. Also, the reaction between oxalate and $\mathrm{Ca}^{2+}$ ions can produce calcium oxalate as an insoluble salt.

$$
\mathrm{CaCO}_{3}+\mathrm{HO}_{2} \mathrm{C}-\mathrm{CO}_{2} \mathrm{H} \rightarrow \mathrm{Ca}\left(\mathrm{C}_{2} \mathrm{O}_{4}\right)+\mathrm{CO}_{2}+\mathrm{H}_{2} \mathrm{O} .
$$

Tu et al. (2007) and Wani (2012) reported that soils with mica and smectite as main minerals as well as calcareous soils could release less $\mathrm{K}$ due to high buffering capacity of soils. Opposite results were also obtained. For example, Jalali and Zarabi (2006) reported that oxalic acid could release more non-exchangeable $\mathrm{K}$ than $\mathrm{CaCl}_{2}$ in some soils. It seems that in their experiments, less $\mathrm{CaCO}_{3}$ is responsible for more $\mathrm{K}$ release when oxalic acid is added.

\section{Conclusions}

The results showed that soils in Kohgiluyeh and Boyer-Ahmad Province, Southwest Iran were classified into 5 orders including Entisols, Inceptisols, Mollisols, Alfisols and Vertisols, of which smectite, chlorite, illite, palygorskite, vermiculite, kaolinite and interstratified illite-smectite were the dominant clay minerals in its clay fraction. The main clay minerals were illite, chlorite and palygorskite in the west and south of Kohgiluyeh and Boyer-Ahmad Province, whereas they were smectite, vermiculite and illite in the north and east of the province. Since a decrease in $\mathrm{CaCO}_{3}$ could result in increases of clay content and clay minerals, there was significant negative correlations of $\mathrm{CCE}$ with exchangeable, non-exchangeable, and structural $\mathrm{K}$. In contrast to structural $\mathrm{K}$, exchangeable and non-exchangeable $\mathrm{K}$ amounts in surface soils were higher than those in subsurface soils. It seems that organic matter plays a more important role than smectite mineral in retaining exchangeable $\mathrm{K}$ in the studied soils. Non-exchangeable $\mathrm{K}$ showed close relationships with illite, vermiculite, smectite, clay content, CEC, OC and CCE. In the study area, some representative pedons that occurred in region with high precipitation such as 51 (Alfisols), 33 (Alfisols), 36 (Molisols), 49 (Alfisols) and 39 (Vertisols) had the higher amount of non-exchangeable $\mathrm{K}$ in surface and subsurface soils, while subsurface soils in Entisols including pedons 53, 29, 34 and 47 had the lower amount of non-exchangeable K. High clay content, smectites with different layer charges and the presence of illite and vermiculite as large reserves of $\mathrm{K}$ are the reasons for the high amount of non-exchangeable $\mathrm{K}$ in these soils. The quantity of structural $\mathrm{K}$ as a $\mathrm{K}$ reserve was depended on vermiculite, high-layer-charge smectite and illite. Structural and non-exchangeable $\mathrm{K}$ amounts were higher in humid regions than in arid and semi-arid regions. Mean cumulative non-exchangeable $\mathrm{K}$ released by $\mathrm{CaCl}_{2}$ was higher than that released by Oxalic acid. This study could provide a scientific reference to reduce $\mathrm{K}$ loss and obtain high crop production in agricultural lands in Kohgiluyeh and Boyer-Ahmad Province, Southwest Iran.

\section{Acknowledgements}

The authors appreciate Shiraz University for providing research facilities. 


\section{References}

Abtahi A. 1977. Effect of a saline and alkaline ground water on soil genesis in semiarid southern Iran. Soil Science Society of America Journal, 41(3): 583-588.

Abtahi A. 1980. Soil genesis as affected by topography and time in highly calcareous parent materials under semiarid conditions in Iran. Soil Science Society of America Journal, 44(2): 329-336.

Anil S, Vikas S, Sanjay A, et al. 2016. Potassium fixation capabilities of some inceptisols belonging to plain and sub-mountainous region. Journal of the Indian Society of Soil Science, 64(4): 368-380.

Barré P, Montagnier C, Chenu C, et al. 2008. Clay minerals as a soil potassium reservoir: observation and quantification through X-ray diffraction. Plant and Soil, 302(1-2): 213-220.

Bhonsle N S, Pal S K, Sekhon G S. 1992. Relationship of K forms and release characteristics with clay mineralogy. Geoderma, 54(1-4): 285-293.

Blanchet G, Libohova Z, Joost S, et al. 2017. Spatial variability of potassium in agricultural soils of the canton of Fribourg, Switzerland. Geoderma, 290: 107-121.

Bouyoucos G J. 1962. Hydrometer method improved for making particle size analyses of soils. Agronomy Journal, 57(5): 464-465.

Buckley D E, Cranston R E. 1971. Atomic absorption analyses of 18 elements from a single decomposition of aluminosilicate. Chemical Geology, 7(4): 273-284.

Chapman H D. 1965. Cation-exchange capacity. In: Black C A. Methods of Soil Analysis. Part 2. Chemical and Microbiological Properties. Madison, WI: Soil Science Society of America, American Society of Agronomy, 891-901.

Conyers E S, McLean E O. 1969. Plant uptake and chemical extractions for evaluating potassium release characteristics of soils. Soil Science Society of America Journal, 33(2): 226-230.

Ghosh B N, Singh R D. 2001. Potassium release characteristics of some soils of Uttar Pradesh hills varying in altitude and their relationship with forms of soil $\mathrm{K}$ and clay mineralogy. Geoderma, 104(1-2): 135-144.

Hashemi S S, Abbaslou H. 2016. Potassium reserves in soils with arid and semi-arid climate in southern Iran: a perspective based on potassium fixation. Iran Agricultural Research, 35(2): 88-95.

Hayashi K, Makino N, Shobatake K, et al. 2014. Influence of scenario uncertainty in agricultural inputs on life cycle greenhouse gas emissions from agricultural production systems: the case of chemical fertilizers in Japan. Journal of Cleaner Production, 73: 109-115.

Hosseinpur A R, Sinegani A A S. 2007. Soil potassium-release characteristics and the correlation of its parameters with garlic plant indices. Communications in Soil Science and Plant Analysis, 38(1-2): 107-118.

Islam A, Saha P K, Biswas J C, et al. 2016. Potassium fertilization in intensive wetland rice system: yield, potassium use efficiency and soil potassium status. International Journal of Agricultural Paper, 1(2): 7-21.

Jackson M L. 1975. Soil Chemical Analysis: Advanced Course. Madison, WI: Department of Soils, College of Agriculture, University Wisconsin, 27-224.

Jalali M. 2006. Kinetics of non-exchangeable potassium release and availability in some calcareous soils of western Iran. Geoderma, 135: 63-71.

Jalali M, Zarabi M. 2006. Kinetics of nonexchangeable-potassium release and plant response in some calcareous soils. Journal of Plant Nutrition and Soil Science, 169(2): 196-204.

Johns W D, Grim R E, Bradley F. 1954. Quantitative estimations of clay minerals by diffraction methods. Journal of Sedimentary Research, 24(4): 242-251.

Khademi H, Mermut A R. 1998. Source of palygorskite in gypsiferous Aridisols and associated sediments from central Iran. Clay Minerals, 33(4): 561-578.

Khormali F, Abtahi A. 2003. Origin and distribution of clay minerals in calcareous arid and semi-arid soils of Fars Province, southern Iran. Clay Minerals, 38(4): 511-527.

Kirkman J H, Basker A, Surapaneni A, et al. 1994. Potassium in the Soils of New Zealand—a review. New Zealand Journal of Agricultural Research, 37(2): 207-227.

Kittrick J A, Hope E W. 1963. A procedure for the particle-size separation of soils for X-ray diffraction analysis. Soil Science, 96(5): 312-325.

Komadel P, Madejová J, Stucki J W. 2006. Structural Fe (III) reduction in smectites. Applied Clay Science, 34(1-4): 88-94.

Li Q X, Jia Z Q, Liu T, et al. 2017. Effects of different plantation types on soil properties after vegetation restoration in an alpine sandy land on the Tibetan Plateau, China. Journal of Arid Land, 9(2): 200-209.

Loeppert R H, Suarez D L. 1996. Carbonate and gypsum. In: Sparks D L. Methods of Soil Analysis. Part 3. Chemical Methods. 
Madison, WI: Soil Science Society of America, American Society of Agronomy, 437-474.

Martin H W, Sparks D L. 1983. Kinetics of nonexchangeable potassium release from two coastal plain soils. Soil Science Society of America Journal, 47(5): 883-887.

McLean E O, Watson M E. 1985. Soil measurements of plant-available potassium. In: Munson R D. Potassium in Agriculture. Madison, WI: Soil Science Society of America, American Society of Agronomy, 277-308.

Mehra O P, Jackson M L. 1960. Iron oxide removal from soils and clays by a dithionite-citrate system buffered with sodium bicarbonate. In: Swineford A. Clays and Clays Minerals. Washington, DC: Pergamon Press, 317-327.

Mengel K, Kirkby E A. 2001. Principles of Plant Nutrition. Dordrecht: Kluwer Academic Publishers, 481-512.

Mengel K. 2006. Potassium. In: Barker A V, Pilbeam D J. Handbook of Plant Nutrition. London: Taylor and Francis Group, 91-120.

Moterle D F, Kaminski J, dos Santos Rheinheimer D, et al. 2016. Impact of potassium fertilization and potassium uptake by plants on soil clay mineral assemblage in South Brazil. Plant and Soil, 406(1-2): 157-172.

Nabiollahy K, Khormali F, Bazargan K, et al. 2006. Forms of K as a function of clay mineralogy and soil development. Clay Minerals, 41(3): 739-749.

Najafi Ghiri M, Abtahi A, Jaberian F, et al. 2010. Relationship between soil potassium forms and mineralogy in highly calcareous soils of southern Iran. Australian Journal of Basic and Applied Sciences, 4(3): 434-441.

Nelson D W, Sommers L E. 1996. Total carbon, organic carbon, and organic matter. In: Sparks D L. Methods of Soil Analysis. Part 3. Chemical Methods. Madison, WI: Soil Science Society of America, American Society of Agronomy, 961-1010.

Owliaie H R, Abtahi A, Heck R J. 2006. Pedogenesis and clay mineralogical investigation of soils formed on gypsiferous and calcareous materials, on a transect, southwestern Iran. Geoderma, 134(1-2): 62-81.

Pratt P F. 1965. Potassium. In: Black C A. Methods of Soil Analysis. Part 2. Chemical and Microbiological Properties. Madison, WI: Soil Science Society of America, American Society of Agronomy, 1022-1030

Raheb A, Heidari A. 2012. Effects of clay mineralogy and physico-chemical properties on potassium availability under soil aquic conditions. Journal of Soil science and Plant Nutrition, 12(4): 747-761.

Rees G L, Pettygrove G S, Southard R J. 2013. Estimating plant-available potassium in potassium-fixing soils. Communications in Soil Science and Plant Analysis, 44(1-4): 741-748.

Richards L A. 1954. Diagnosis and Improvement of Saline and Alkali Soils (Handbook No. 60). Washington: United States Salinity Laboratory, 1-160.

Schindler F V, Woodard H W, Doolittle J J. 2003. Reduction-oxidation effects on soil potassium and plant uptake. Communications in Soil Science and Plant Analysis, 34(9-10): 1407-1419.

Sharpley A N. 1989. Relationship between soil potassium forms and mineralogy. Soil Science Society of America Journal, 53(4): 1023-1028.

Soil Survey Staff. 2014. Keys to Soil Taxonomy (2 ${ }^{\text {nd }}$ ed.). Washington, DC: USDA, NRCS, 43-316.

Sparks D L, Huang P M. 1985. Physical chemistry of soil potassium. In: Munson R D. Potassium in Agriculture. Madison, WI: Soil Science Society of America, American Society of Agronomy, 201-276.

Sparks D L. 2000. Bioavailability of soil potassium. In: Sumner M E. Handbook of Soil Science. Boca Raton: CRC Press, 38-52.

Tan D S, Liu Z H, Jiang L H, et al. 2017. Long-term potash application and wheat straw return reduced soil potassium fixation and affected crop yields in North China. Nutrient Cycling in Agroecosystems, 108(2): 121-133.

Tu S X, Guo Z F, Sun J H. 2007. Effect of oxalic acid on potassium release from typical Chinese soils and minerals. Pedosphere, 17(4): 457-466.

Wani M A. 2012. Oxalic acid effect on potassium release from typical rice soils of Kashmir. Communications in Soil Science and Plant Analysis, 43(8): 1136-1148.

Wood R A, Schroeder B L. 1991. Release of non-exchangeable potassium reserves from a range of sugar industry soils. Proceedings of The South African Sugar Technologists' Association, 65: 47-52.

Xie Q Q, Chen T H, Zhou H, et al. 2013. Mechanism of palygorskite formation in the Red Clay Formation on the Chinese Loess Plateau, northwest China. Geoderma, 192: 39-49.

Zhan L P, Li X K, Lu J W, et al. 2014. Potassium fixation and release characteristics of several normal and K-exhausted soils in the middle and lower reaches of the Yangtse River, China. Communications in Soil Science and Plant Analysis, 45(22): 2921-2931.

Zhang Y G, Yang S, Fu M M, et al. 2015. Sheep manure application increases soil exchangeable base cations in a semi-arid steppe of Inner Mongolia. Journal of Arid Land, 7(3): 361-369. 